Pemanfaatan Jurnal Online Perpustakaan BPTP Yogyakarta Dwi Titaningsih, Suharno

Kerja Sama antara SDM Perpustakaan untuk Menuju Layanan Prima dan Unggul Endang Fatmawati

Revitalisasi Peran Perpustakaan Umum bagi Masyarakat Noorika Retno Widuri

Optimalisasi Layanan Penelusuran Sumber-sumber Informasi untuk Mendukung Penulisan Karya Ilmiah Dosen dan Mahasiswa di Perguruan Tinggi Dian Hapsari

Memperkuat Peran Pustakawan dalam Mewujudkan Layanan Perpustakaan Perguruan Tinggi yang Prima dan Unggul Bambang Hermanto

Aktivitas Mahasiswa dalam Membaca Skripsi di Perpustakaan Masriyatun

Budaya Peduli dan Budaya Mutu Melayani di Perpustakaan SMP Negeri 13 Surakarta Menuju Sekolah Menyenangkan Ria Widyawati

Redesain Website UPT Perpustakaan Universitas Sebelas Maret sebagai Media Pendidikan Pengguna bagi Pemustaka Tri Hardian Satiawardana

Peran Perpustakaan dalam Membangun Citra Perpustakaan di Era Teknologi Informasi Sri Anawati

Komunitas Pustakawan Menulis (upaya menyebarluaskan dan melestarikan pengetahuan) Tri Hardiningtyas 


\section{Jurnal}

\section{Pustaka Ilmiah}

\section{Jurnal Ilmiah UPT Perpustakaan UNS}

Jurnal Pustaka Ilmiah (JPI) sebagai media kreasi para pustakawan, guru, dosen, dan praktisi dalam pengembangan profesi secara berkelanjutan. Berbagai ide dan gagasan kreatif menjadi bahan kajian yang diimplementasikan dalam berbagai model pengembangan bahan pustaka, baik cetak maupun online. Kreativitas menjadi akar pengembangan ilmu pengetahuan sepanjang hayat dengan berbagai model pengembangan budaya literasi di perpustakaan. Keindahan dan kecermatan dalam sebuah tulisan ilmiah dan nonilmiah akan dapat direalisasikan secara nyata oleh sumber daya manusia untuk menghasilkan SDM yang unggul dan kreatif dengan membaca dan menulis untuk menyinari dunia. Budaya literasi menjadi upaya untuk pengembangan dan pemberdayaan perpustakaan sebagai pusat sumber belajar untuk mendukung tri dharma perguruan tinggi.

\section{SUSUNAN REDAKSI}

Penanggung Jawab

Ketua Redaksi

Wakil Redaksi

Sekretaris

Penyunting Ahli

Penyunting

Bendahara

Sirkulasi
: Dr. Muhammad Rohmadi, M.Hum.

: Dra. Tri Hardiningtyas, M.Si.

: Haryanto, M.IP.

: Bambang Hermanto, S.Pd., M.IP., Henny Perwitosari, A.Md.

: 1. Dr. Muhammad Rohmadi, M.Hum. (Universitas Sebelas Maret);

2. Drs. Widodo, M.Soc.Sc. (Universitas Sebelas Maret);

3. Drs. Harmawan, M.Lib. (Universitas Sebelas Maret).

: Daryono, S.Sos., M.IP.; RiahWiratningsih, S.S., M.Si., Dinar Puspita Dewi, S.Sos., M.IP.; Sri Utari, S.E.

: Nurul H., A. Md.; Novi Tri Astuti, A.Md.

: Aji Hartono, A. Md.; Agus Sriyono, A.Md.; Aris Suprihadi, S.IP.

UPT PERPUSTAKAAN UNS

REDAKSI JURNAL PUSTAKA ILMIAH

Alamat: Jl. Ir. Sutami 36A Kentingan, Surakarta 57126

Telp./Fax.: (0271) 654311; email: jurnal.pustaka.ilmiah@gmail.com 


\section{Pengantar Redaksi}

\section{Salam Pustaka.}

Dengan mengucap rasa syukur kepada Allah SWT. segenap Tim Redaksi Jurnal Pustaka Ilmiah (JPI) mengucapkan banyak terima kasih kepada para penulis yang telah berkontribusi untuk penerbitan JPI volume 2 edisi Juni 2016. Penerbitan volume 2 kali ini JPI mengetengahkan tema: Pengembangan Perpustakaan menuju Layanan Prima dan Unggul. Kehadiran JPI diharapkan dapat dijadikan sebagai media penulisan bagi para pustakawan, dosen, tenaga kependidikan, guru, dan praktisi untuk menuangkan ide dan gagasan kreatifnya secara tertulis.

Dalam penerbitan JPI volume 2 bulan Juni 2016 ini disajikan sepuluh tulisan antara lain: (1) Pemanfaatan Jurnal Online Perpustakaan BPTP Yogyakarta (Dwi Titaningsih dan Suharno), (2) Kerja Sama Antara Sumber Daya Manusia Perpustakaan untuk Menuju Layanan Prima dan Unggul (Endang Fatmawati), (3) Revitalisasi Peran Perpustakaan Umum Bagi Masyarakat (Noorika Retno Widuri), (4) Optimalisasi Layanan Penelusuran Sumber-Sumber Informasi untuk Mendukung Penulisan Karya Ilmiah Dosen dan Mahasiswa di Perguruan Tinggi (Dian Hapsari), (5) Memperkuat Peran Pustakawan dalam Mewujudkan Layanan Perpustakaan Perguruan Tinggi yang Prima dan Unggul (Bambang Hemanto), (6) Aktivitas Mahasiswa dalam Membaca Skripsi di Perpustakaan FISIP-UNS (Masriyatun), (7) Budaya Peduli dan Budaya Mutu Melayani di Perpustakaan SMP Negeri 13 Surakarta Menuju Sekolah Menyenangkan (Ria Widyawati), (8) Redesain Website UPT Perpustakaan Universitas Sebelas Maret Surakarta sebagai Media Pendidikan Pengguna Bagi Pemustaka (Tri Hardian Satiawardana), (9) Peran Perpustakaan dalam Membangun Citra Perpustakaan di Era Teknologi Informasi (Sri Anawati), (10) Komunitas Pustakawan Menulis : upaya menyebarluaskan dan melestarikan pengetahuan (Tri Hardiningtyas).

Akhirnya, redaksi JPI mengucapkan banyak terima kasih kepada Kepala UPT Perpustakaan UNS yang telah memberikan dukungan dan memfasilitasi untuk penerbitan JPI. Selain itu, ucapan terima kasih juga disampaikan kepada para penulis, tim redaksi, dan Yuma Pressindo, yang telah mempersiapkan dari awal sampai terbitnya JPI. Selamat membaca.

Surakarta, Juni 2016

Ketua Redaksi 


\section{Sambutan}

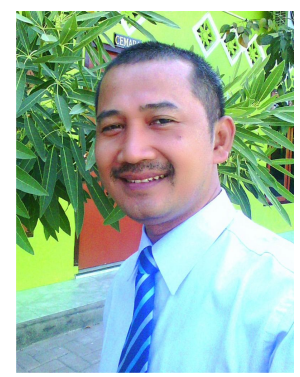

Dr. Muhammad Rohmadi, M.Hum.

\section{Kepala UPT Perpustakaan UNS}

Selamat dan sukses atas diterbitkannya kembali Jurnal Pustaka Ilmiah (JPI). Jurnal ini sebagai media kreativitas dan pengembangan softs skills para pustakawan, guru, dosen, dan praktisi untuk menuangkan ide dan gagasan demi layanan perpustakaan yang prima dan unggul. Berbagai isu terkait dengan pengembangan perpustakaan, pelayanan perpustakaan sebagai pusat sumber belajar, pendidikan, penelitian, pelestarian, dan budaya literasi akan menjadi topik-topik yang disajikan dalam jurnal ilmiah ini.

Diterbitkannya JPI sebagai bukti kepedulian UPT Perpustakaan Universitas Sebelas Maret Surakarta (UNS) dalam rangka turut berpartisipasi mengembangkan dan membudayakan literasi untuk para pustakawan dan civitas akademika di UNS maupun luar UNS. Berbagai model pengembangan softs skills menjadi alternatif untuk membekali dan memperkuat jaringan kerja sama penulisan antar kelembagaan. Dengan demikian, kerja sama antar pustakawan dan pemustaka dapat diwujudkan dengan berbagai model dalam bidang literasi.

Penerbitan JPI merupakan sarana untuk memotivasi semua pustakawan agar berkarya di bidang penulisan, baik ilmiah maupun nonilmiah. Para pustakawan harus menjadi pionir dalam bidang penulisan. Hal ini sebagai bentuk kepedulian dan keteladaan para pustakawan yang memproses, menyajikan, dan menikmati bahan-bahan pustaka cetak dan noncetak di perpustakaan. Ketersedian bahan pustaka akan menjadi bahan paling nyata untuk dikembangkan dalam berbagai model perwujudan teknik penulisan. Hal terpenting yang harus dimiliki oleh para pustakawan adalah semangat untuk berbagi pengetahuan melalui tulisan.

Kepedulian setiap sumber daya manusia kepada kelembagaan dapat dituangkan dalam berbagai model pengabdian, salah satunya adalah melalui tulisan. Berbagai ide dan gagasan dapat direalisasikan dengan berbagai model bentuk artikel jurnal, buku, modul, monograf, dan lain sebagainya. Para civitas akademika, guru, praktisi harus memiliki keterampilan menulis sebagai bentuk perwujudan pengembangan diri secara berkelanjutan. Berbagai tulisan dan referensi sudah disajikan tetapi masih sangat minim untuk diimplementasikan dalam kehidupan. Banyak orang pandai dalam berbicara tetapi masih sedikit yang menuangkan ide dan gagasannya dalam bentuk tulisan.

Akhirnya, keluarga besar UPT Perpustakaan UNS mengucapkan banyak terima kasih kepada Rektor, Wakil Rektor, pengelola JPI, penulis, dan semua pihak yang telah mendukung penerbitan JPI. Semoga dengan diterbitkannya JPI ini dapat menjadi media untuk menulis para pustakawan, dosen, guru, dan praktisi dalam bidang iptek dan seni. Ucapan terima kasih juga diucapkan kepada percetakan Yuma Pressindo yang telah membantu mempersiapkan dari awal sampai terbitnya JPI ini. Akhirnya, semoga JPI dapat memberikan nilai kemaslahatan untuk umat. 


\section{DAFTAR ISI}

\section{JURNAL PUSTAKA ILMIAH EDISI KEDUA: VOLUME 1 NOMOR 2/ JUNI 2016}

\section{Tema: Pengembangan Perpustakaan Menuju Layanan Prima dan Unggul}

Pemanfaatan Jurnal Online Perpustakaan BPTP Yogyakarta

Dwi Titaningsih, Suharno

Kerja Sama antara SDM Perpustakaan untuk Menuju Layanan Prima dan Unggul

Endang Fatmawati

Revitalisasi Peran Perpustakaan Umum bagi Masyarakat.

Noorika Retno Widuri

Optimalisasi Layanan Penelusuran Sumber-sumber Informasi untuk Mendukung Penulisan Karya Ilmiah Dosen dan Mahasiswa di Perguruan Tinggi..

Dian Hapsari

Memperkuat Peran Pustakawan dalam Mewujudkan Layanan Perpustakaan Perguruan Tinggi yang Prima dan Unggul.

Bambang Hermanto

Aktivitas Mahasiswa dalam Membaca Skripsi di Perpustakaan

Masriyatun

Budaya Peduli dan Budaya Mutu Melayani di Perpustakaan SMP Negeri 13 SurakartaMenuju SekolahMenyenangkan.

Ria Widyawati

Redesain Website UPT Perpustakaan Universitas Sebelas Maret sebagai Media Pendidikan Pengguna bagi Pemustaka.

Tri Hardian Satiawardana

Peran Perpustakaan dalam Membangun Citra Perpustakaan di Era Teknologi Informasi

Sri Anawati

Komunitas Pustakawan Menulis (upaya menyebarluaskan dan melestarikan pengetahuan)

Tri Hardiningtyas 


\title{
REVITALISASI PERAN PERPUSTAKAAN UMUM BAGI MASYARAKAT
}

\author{
Noorika Retno Widuri \\ UPT Balai Informasi Teknologi LIPI \\ Email: noorika@yahoo.com
}

\begin{abstract}
The positive development of the various plans of the central government and local government in revitalizing the function of the library in the middle of the community deserve an immediate response by the relevant stakeholders in librarianship. This avoids the loss of state spending because of the development budget of the library, while the library can not be used optimally by the community. In addition to causing harm to the state budget, the failure of the revitalization of the public library functions have an impact on the loss of public confidence in the library. See some interesting phenomenon, the author argues that it is time the library needs to revitalize its role for the community. The issue raised is how the shape of revitalizing the role of the public library for the community.
\end{abstract}

There are several factors driving the revitalization of the role of libraries, namely the advancement of information and communication technologies, the increasing mobility of educated people and high society. The revitalization of the role of public libraries include the library as a social change agent, the agent of human development and cultural agents. Revitalization activities the library's role as change agents are providing a variety of programs that present a public library, according to the dynamics of today's society, setting up community-based public library. Revitalize the role of the public library into a public space as a catalyst for social activities, recreation, and culture of the citizens, and to make the library more dynamic, practical and humane.

Revitalizing the role of the public library as part of a public service by applying the standard ISO 9008: 2008 in libraries, innovation bureaucracy and library services, as well as professional certification library manager.

Keywords: revitalization of the library; the role of the library; public Library; agents of social change; public service

\begin{abstract}
ABSTRAK
Perkembangan positif mengenai berbagai rencana pemerintah pusat dan pemerintah daerah dalam menghidupkan kembali fungsi perpustakaan di tengah-tengah masyarakat perlu mendapat tanggapan segera oleh para stakeholder terkait bidang kepustakawanan. Hal ini menghindari kerugian belanja negara karena besarnya anggaran pembangunan perpustakaan, sedangkan perpustakaan tersebut tidak bisa dimanfaatkan secara optimal oleh masyarakat. Selain dapat menyebabkan kerugian pada belanja negara, gagalnya revitalisasi fungsi perpustakaan umum berdampak pada hilangnya tingkat kepercayaan masyarakat pada perpustakaan. Melihat beberapa fenomena menarik ini, penulis berpendapat bahwa inilah saatnya perpustakaan perlu merevitalisasi perannya bagi masyarakat. Ada pun permasalahan yang diangkat adalah bagaimana bentuk revitalisasi peran perpustakaan umum bagi masyarakat. Ada beberapa faktor pendorong revitalisasi peran perpustakaan, yakni kemajuan teknologi informasi dan
\end{abstract}


komunikasi, meningkatnya masyarakat yang berpendidikan dan mobilitas masyarakat yang tinggi. Ada pun revitalisasi peran perpustakaan umum, di antaranya adalah perpustakaan sebagai agen perubahan sosial, agen pembangunan, dan agen budaya manusia. Kegiatan revitalisasi peran perpustakaan sebagai agen perubahan, antara lain menyiapkan berbagai program perpustakaan umum yang kekinian, sesuai dengan dinamika masyarakat saat ini, menyiapkan perpustakaan umum berbasis komunitas. Merevitalisasi peran perpustakaan umum menjadi ruang publik sebagai salah satu katalisator kegiatan-kegiatan sosial, rekreasi, dan budaya warga kota, serta menjadikan perpustakaan lebih dinamis, praktis dan humanis. Revitalisasi peran perpustakaan umum sebagai bagian dari pelayanan publik dengan menerapkan standar ISO 9008:2008 pada perpustakaan, inovasi birokrasi dan pelayanan perpustakaan, serta sertifikasi profesi pengelola perpustakaan.

Kata kunci: revitalisasi, perpustakaan umum, pelayanan publik

\section{PENDAHULUAN}

Artikel ini berangkat dari pemikiran penulis mengenai peran perpustakaan umum saat ini, yang seharusnya justru menjadi sangat vital, namun tidak demikian yang terjadi. Perubahan teknologi informasi dan komunikasi yang begitu booming, malah menenggelamkan peran perpustakaan di Indonesia. Masyarakat malah menganggap kehadiran warnet dan gadget sebagai dewa penolong saat mereka membutuhkan informasi. Di mana posisi perpustakaan umum saat ini ? Apakah perpustakaan terlambat merespons sebuah perubahan besar dalam masyarakat?

Sebuah pendapat kritis disampaikan Taufik Asmiyanto pada Rakerpus IPI XIII di Pekanbaru 2005 silam bahwa kondisi perpustakaan di Indonesia pascarezim Orde Baru ternyata belum juga memperlihatkan ke arah yang lebih baik. Walaupun perpustakaan tidak lagi dijadikan ideologi pemerintahan yang berkuasa, namun perpustakaan tetap tidak mampu menempatkan diri sebagai ruang publik. Perpustakaan tidak mampu memenuhi kebutuhan publik dan menjamin akses publik untuk berperan serta dalam diskursus yang menyangkut kepentingan bersama. Perpustakaan juga tidak mampu berperan aktif dalam turut mendukung terciptanya demokratisasi dan terbentuknya masyarakat madani (Asmiyanto, 2005).
Pada Desember 2015 lalu, pemerintah DIY meresmikan perpustakaan Graha Tama Pustaka. Perpustakaan yang berdiri di atas lahan seluas 2,4 hektare menghabiskan anggaran sekitar Rp 70 miliar tersebut dilengkapi dengan ruang bercerita anak-anak, bioskop, ruang teater, serta ruang audio visual. Di samping itu, dilengkapi fasilitas tempat berjualan makanan (Ridarineni, 2015).

Kabarnya, Pemerintah Provinsi Lampung juga akan membangun perpustakaan terbaik dan terbesar di Indonesia senilai Rp 100 miliar. Rencananya, gedung perpustakaan tersebut akan dilengkapi ruang seminar, ruang publik, ruang baca rekreatif, ruang bermain anak, ruang e-library, baca anak, audio visual, diorama, rumah makan, dan lainnya, demikian menurut Asisten Bidang Administrasi Umum Setprov Lampung, Hamartoni Alhadist, di Bandar Lampung (tempo.co, 2016).

Di Bandung, Walikota Bandung, Ridwan Kamil menggagas lahirnya Micro-Library di Taman Lansia Kota Bandung. Ridwan Kamil juga mendesain Micro-Library di Kampung Arjuna. Bawah untuk serba guna, atas untuk rak buku-buku. Dinding dari jerigen-jerigen bekas yang di daur ulang. Bagian dari program peningkatan minat baca di kampung-kampung Bandung. Pemberitaan mengenai beberapa pemerintah daerah yang mulai membangun 
perpustakaan sepertinya membawa angin segar mengenai eksistensi perpustakaan di tengahtengah masyarakat.

Berita terkininya, rencana DPR membangun perpustakaan yang menghabiskan biaya fantastis, sebesar Rp 570 miliar yang sudah dianggarkan di APBN 2016. Meski menuai berbagai kontroversi, perpustakaan ini nantinya akan menjadi yang terbesar di Asia Tenggara. Angin segar bagi dunia kepustakawanan tentunya. Beberapa pemerintah daerah mempunyai rencana besar untuk membangun perpustakaan. Artinya, para stakeholder mulai menyadari bahwa perpustakaan sebenarnya sangat diperlukan keberadaannya di tengahtengah masyarakat, berada di pusaran aktivitas masyarakat.

Perkembangan positif mengenai berbagai rencana pemerintah pusat dan pemerintah daerah dalam menghidupkan kembali fungsi perpustakaan di tengah-tengah masyarakat perlu mendapat tanggapan segera oleh para stakeholder terkait bidang kepustakawanan. Hal ini menghindari kerugian belanja negara karena besarnya anggaran pembangunan perpustakaan, sedangkan perpustakaan tersebut tidak bisa dimanfaatkan secara optimal oleh masyarakat. Selain dapat menyebabkan kerugian pada belanja negara, gagalnya revitalisasi fungsi perpustakaan umum berdampak pada hilangnya tingkat kepercayaan masyarakat pada perpustakaan. Padahal seperti yang diberitakan Kompas, 20 April 2016 lalu, bahwa di seluruh dunia, perpustakaan terbukti bisa ikut berperan menyediakan kesempatan bagi masyarakat untuk mengembangkan dirinya, keluar dari ketidaksetaraan dan kemiskinan lewat keterbukaan akses informasi digital dan pengetetahuan. Kondisi perpustakaan umum di Indonesia perlu segera dicarikan solusi permasalahannya, salah satunya dengan merevitaslisasi perannya agar bisa langsung mengena ke masyarakat.
Melihat beberapa fenomena menarik ini, penulis berpendapat bahwa inilah saatnya perpustakaan perlu merevitalisasi perannya bagi masyarakat. Ada pun permasalahan yang diangkat adalah bagaimana bentuk revitalisasi peran perpustakaan umum bagi masyarakat.

\section{PEMBAHASAN}

\section{Mengapa Perlu Revitalisasi Peran Perpustakaan?}

Revitalisasi secara harfiah berarti kegiatan untuk menyadarkan, menyegarkan kembali, menghidupkan kembali, atau membangkitkan kembali (Echols \& Shadily, 1992). Revitalisasi (dalam KBBI online) adalah proses, cara, perbuatan menghidupkan atau menggiatkan kembali. Mengacu dari beberapa pengertian revitalisasi di atas, maka revitalisasi fungsi perpustakaan umum bagi masyarakat adalah usaha yang dilakukan agar perpustakaan umum dapat memegang fungsi sebagaimana mestinya.

Ada beberapa faktor pendorong revitalisasi peran perpustakaan, antara lain:

a. Kemajuan teknologi informasi dan komunikasi. Perkembangan teknologi yang pesat tidak selalu dapat diikuti oleh semua lapisan masyarakat. Di dalam perpustakaan, diharapkan masyarakat dapat melihat dan merasakan tahapan perkembangan teknologi tersebut, khususnya perkembangan media informasi. Perubahan pola komunikasi masyarakat juga memiliki kontribusi pada perubahan pola komunikasi antara perpustakaan dan masyarakat. Termasuk di dalamnya, perubahan interaksi antarmasyarakat, masyarakat dengan pemerintah, dan pemerintah dengan pemerintah.

b. Meningkatnya masyarakat yang berpendidikan. Kelompok masyarakat berpendidikan tinggiakan meningkat seiring tuntutan zaman, di mana isu pekerjaan menjadi salah satu pendorong meningkatnya 
kelompok ini. Kecenderungan peningkatan pendidikan dalam masyarakat semakin meningkatkan kebutuhan akan informasi. Perpustakaan yang baik mampu membaca peluang ini dengan memberikan aksesakses penting dan pelayanan khusus bagi kelompok masyarakat ini.

c. Nurtakyidah (2013) menuturkan bahwa terjadinya mobilitas masyarakat yang tinggi juga mendorong revitalisasi peran perpustakaan. Tingginya mobilitas masyarakat terjadi karena faktor pendidikan dan pekerjaan. Urbanisasi, baik pekerja maupun mahasiswa membuat kelompok ini tetap menjalin hubungan dengan daerah asal melalui koneksi internet. Jadi, sewajarnya perpustakaan memberikan pelayanan akses internet.

\section{Revitalisasi Peran Perpustakaan Umum} sebagai Agen Perubahan Sosial, Agen Pembangunan, dan Agen Budaya Manusia.

Sinaga (2004) mengatakan bahwa perpustakaan baru dikatakan menjadi agen perubahan sosial jika: (a) perpustakaan memberikan kontribusi bagi kehidupan keluarga sebagai unit kehidupan sosial, (b) dapat menolong masyarakat memanfaatkan waktu luang menjadi lebih manfaat, (c) dapat meningkatkankehidupandemokrasidanmenjadi warga negara yang baik, (d) dapat dimanfaatkan sebagai instrumen untuk menumbuhkan keinginan belajar yang berkelanjutan, dan (e) perpustakaan dapat memberikan kontribusi penting dalam menumbuhkan ekonomi masyarakat.

Kegiatan revitalisasi peran perpustakaan sebagai agen perubahan, di antaranya sebagai berikut:

a. Menyiapkanberbagaiprogramperpustakaan umum yang kekinian, yang sesuai dengan dinamika perkembangan masyarakat saat ini. b. Menyiapkan perpustakaan umum berbasis komunitas. Perpustakaan sebagai perwujudan ruang komunal tempat pembelajaran antarmanusia satu dengan yang lain, komunitas satu dengan yang lain. Masyarakat pemustaka dapat membebaskan diri dari kebodohan dan minimnya pengetahuan agar masyarakat terbebas dari dampak negatif. Kartika (2010) menuturkan bahwa gambaran ruang komunal yang berkembang dalam deskripsi masyarakat adalah sebuah ruangan terbuka yang bercirikan suasana alamiah seperti sebuah taman kota. Dengan menangkap sebuah fenomena tersebut, bagaimana mencoba menduplikasikan suasana tersebut dalam sebuah bangunan perpustakaan. Hal ini sebagai sebuah pendekatan dari penguatan citra ruang komunal.

c. Peran perpustakaan umum menjadi ruang publik, membuka peluang perpustakaan untuk meluncur dari stereotype perpustakaan yang membosankan, tidak menarik, kurang atraktif dan interaktif. Perpustakaan umum sebagai wadah (melting pot $)^{1}$ bertemunya seluruh warga kota dengan berbagai ragam nilai yang dianutnya. Indonesia terkenal dengan kebhinekaannya, beraneka suku berbaur menjadi satu dalam satu wadah, menyatukan keberagaman dalam aktivitas yang positif. Perpustakaan merupakan "wadah" paling tepat karena perpustakaan dianggap netral dan tidak ada keberpihakan dengan politik maupun berbagai kepentingan lainnya.

d. Perpustakaan berfungsi sebagai sebagai katalisator $^{2} \quad$ kegiatan-kegiatan sosial,

1 melting pot adalah bercampurnya manusia dalam latar belakang etnik yang berbeda, kemudian "meleleh" menjadi manusia baru. (Multikulturalisme di Perancis, Joasana Tjahyani, FIB UI)

2 katalisator dalam KBBI adalah seseorang atau sesuatu yang menyebabkan ter- 
rekreasi, dan budaya warga kota. bagi peningkatan mutu layanan informasinya. Perpustakaan menjadi hidup dan dinamis. Sebab, ISO fokus pada perbaikan sistem mutu Berbagai kegiatan hiburan dan belajar layanan informasi yang berorientasi pada sepanjang hayat seperti writing camp untuk kebutuhan pengguna/pemustaka. Sistem mutu anak, diskusi buku, aneka lomba gambar ini bertujuan untuk meningkatkan kepuasan dan mewarnai, serta kegiatan-kegiatan pelanggan/pemustaka melalui penerapan sistem yang menghibur dan pastinya membuat kesan perpustakaan yang tidak lagi sunyi dan sepi, launching dan bedah buku-buku terbaru, terutama karya penulis-penulis local.

e. Perpustakaan menjadi dinamis, praktis, dan humanis (Junaenah, 2014). Memperbaiki tampilan fisik yang colourfull dengan desain yang "kekinian" sesuai dengan tren sekarang. Perpustakaan menyediakan koleksi yang disesuaikan dengan pemustaka saat ini. Penuhi perpustakaan dengan koleksi paket keluarga untuk ayah, ibu, dan anak. Buku-buku motivasi dan hiburan yang ringan, koleksi CD interaktif, dan internet dengan kecepatan tinggi.

\section{Revitalisasi Peran Perpustakaan Umum sebagai Bagian dari Pelayanan Publik}

Undang-Undang nomor 25 tahun 2009 mengenai pelayanan publik menegaskan bahwa negara berkewajiban melayani setiap masyarakat sehingga ada standar pelayanan sebagai penilaian suatu kualitas layanan.

\section{a. ISO 9001:2008}

Kualitas pelayanan publik dapat ditingkatkan dengan memperbaiki beberapa hal terkait manajemen dan sumber daya manusianya, serta mengembangkan berbagai inovasi-inovasi untuk pembaruan layanan. Salah satunya adalah perbaikan manajemen pelayanan publik, dengan menerapkan ISO 9001:2008 di perpustakaan umum.

Layanan berkualitas diwujudkan melalui sistem formal, salah satunya ISO. Penerapan sistem manajemen mutu ISO 9001:2008 bagi perpustakaan memberikan dampak positif jadinya perubahan dan menimbulkan kejadian baru atau mempercepat suatu peristiwa yang efektif, termasuk proses untuk perbaikan sistem secara berkesinambungan dan jaminan kesesuaian dengan persyaratan pelanggan, regulasi, dan peraturan perundang-undangan yang berlaku. Pada ISO 9001:2008 Sistem Manajemen Mutu bagi Perpustakaan, berikut adalah klausul 4 Sistem Manajemen Mutu Perpustakaan:

1) mendokumentasikan, menerapkan, dan memelihara sistem manajemen mutu dan terus-menerus memperbaiki efektivitas,

2) menentukan proses,

3) menetapkan urutan dan interaksi,

4) menetapkan kriteria dan metode,

5) memastikan tersedianya sumber daya dan informasi,

6) memantau, mengukur, dan menganalisis proses,

7) koreksi berkesinambungan dari proses tersebut,

8) harus memiliki kebijakan mutu, sasaran mutu, manual mutu, prosedur, dan rekaman terdokumentasi yang disyaratkan oleh standar ini, dan dokumen, termasuk rekaman yang ditetapkan oleh organisasi perlu untuk memastikan efektivitas perencanaan, operasi, dan kendali prosesnya

\section{b. Inovasi Birokrasi dan Pelayanan Perpustakaan}

Inovasi menurut KBBI adalah pemasukan atau pengenalan hal-hal yang baru; pembaharuan atau penemuan baru yang berbeda dari yang sudah ada atau yang sudah dikenal sebelumnya (gagasan, metode, atau alat). Mengapa inovasi birokrasi dan layanan perpustakaan merupakan salah satu yang harus direvitalisasi? Agar perpustakaan berperan lebih dinamis dan kekinian. Perpustakaan yang berstatus milik 
pemerintah selalu terkait dengan birokrasi. Di Indonesia, birokrasi dianggap bertele-tele dan rumit. Dengan inovasi bidang birokrasi yang berkembang saat ini, memungkinkan perpustakaan juga mengembangkan berbagai layanan inovatifnya.

Pada tahun 2014 Kementerian PAN-RB menyelenggarakan kompetisi inovasi pelayanan publik, yang dipilih hanya Top 99 Inovasi. Badan Perpustakaan Provinsi Kalimantan Timur muncul dengan inovasi penerapan layanan perpustakaan berbasis teknologi informasi. Inovasi ini diharapkan dapat mendongkrak citra positif perpustakaan dan pustakawan di masyarakat, yang hanya dapat dilakukan dengan pendekatan program peningkatan kualitas layanan perpustakaan dengan menerapkan layanan perpustakaan berbasis teknologi informasi (otomasi perpustakaan).

Inovasi tahun 2014 lainnya, yakni internet kecamatan sehat gratis di salah satu taman kota di Madiun. Internet sehat gratis merupakan layanan koneksi internet secara gratis yang diselenggarakan oleh Pemerintah di tingkat kecamatan dengan content yang terseleksi. Kegiatan internet sehat gratis ini untuk mendukung layanan administrasi kependudukan dan guna mendorong pemanfaatan teknologi informasi dan komunikasi dalam rangka peningkatan kecerdasan warga dan kesejahteraan masyarakat. Kegiatan ini dapat berjalan apabila pimpinan daerah berkomitmen untuk meningkatkan pelayanan publik. Layanan Internet sehat gratis ini pun bisa diadopsi oleh perpustakaan umum,

Kantor Arsip dan Perpustakaan Daerah Kota Yogya mengembangkan inovasi Bank Buku yang masuk dalam 99 Inovasi Layanan Publik tahun 2014. Bank Buku adalah wadah bagi masyarakat untuk dapat menyumbangkan buku layak pakai melalui Perpustakaan
Kota Yogyakarta. Buku sumbangan tersebut kemudian akan didistribusikan secara luas bagi masyarakat yang membutuhkan. Yang terbaru, di tahun tahun 2016 ini, Badan Perpustakaan dan Arsip Daerah Propinsi Jawa Barat meraih 99 Inovasi Pelayanan Publik dengan judul Wajah Baru Layanan Perpustakaan Umum Jawa Barat.

Revitalisasi peran perpustakaan umum dengan meningkatnya berbagai inovasi layanan perpustakaan menunjukkan perpustakaan berkembang sesuai minat pemustaka yang dilayaninya. Birokrasi dan perpustakaan dengan stereotype lama harus diubah guna meningkatkan dan menghidupkan perannya kembali bagi masyarakat.

\section{c. Sertifikasi Profesi Pengelola Perpustakaan}

Sumber daya pengelola perpustakaan menjadi aspek vital dalam pelayanan perpustakaan. Saat ini, Badan Nasional Standarisasi Profesi sudah melakukan kegiatan sertifikasi pustakawan. Hal ini menjadi salah satu bukti keseriusan pemerintah bahwa setiap profesi atau pekerjaan memiliki skill atau keahlian yang betul-betul mumpuni di bidangnya.

Dasar hukum sertifikasi pustakawan sesuai dengan Keputusan Menteri Tenaga Kerja dan Transmigrasi Republik Indonesia nomor 83 tahun 2012 tentang penetapan rancangan standar kompetensi kerja nasional Indonesia sektor jasa kemasyarakatan, hiburan, dan perorangan lainnya bidang perpustakaan menjadi standar kompetensi kerja nasional Indonesia. Dengan sumber daya pustakawan dan pengelola perpustakaan yang sudah memiliki sertifikasi, diharapkan dapat berkontribusi aktif dalam mengembangkan peran perpustakaan umum di wilayahnya. 


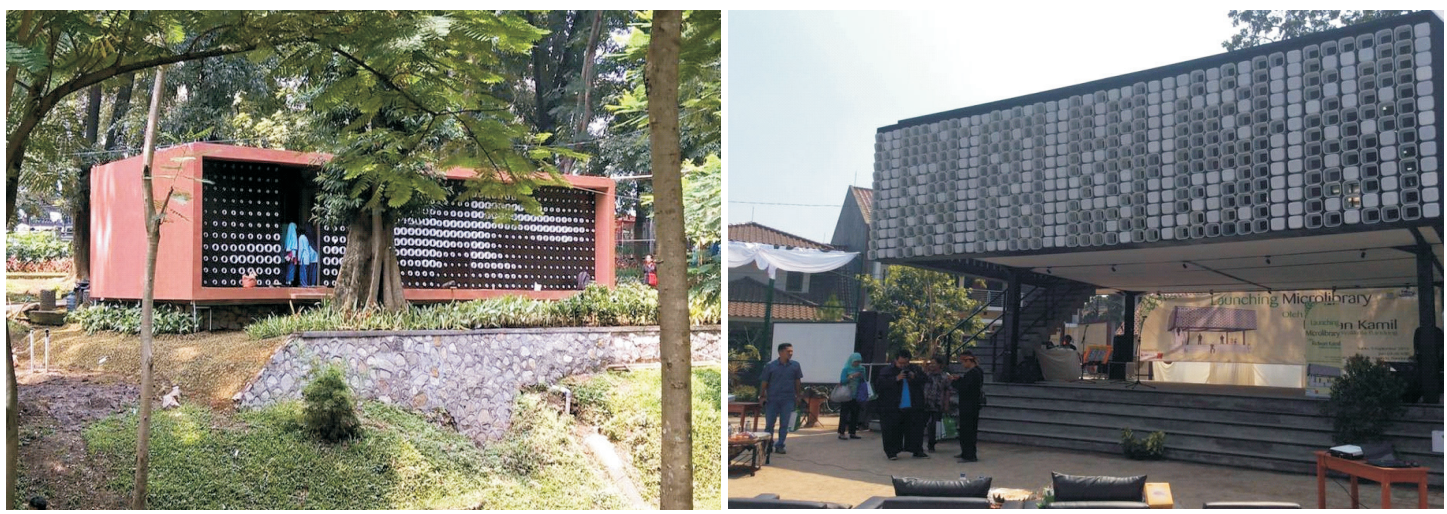

Gambar 1 Micro-Library yang Digagas Walikota Bandung, Ridwan Kamil di Taman Lansia dan Kampung Arjuna, Bandung (Sumber: facebook Ridwan Kamil)

\section{PENUTUP}

The Library is a Growing Organism, hukum kelima Ranganatan ini memberi tahu kepada kita bahwa yang terpenting dari perpustakaan adalah bahwa perpustakaan itu selalu tumbuh dan berkembang serta berubah dan akan selalu mengalami hal seperti itu. Koleksi perpustakaan selalu bertambah dan berubah, teknologi terus berkembang maju dan budget juga selalu mengikuti perubahan itu. Perubahan-perubahan yang kompleks tersebut harus diantisipasi dan diimbangi dengan manajemen yang baik (Zulaikha, 2008).
Demikian pula dengan dinamika perubahan di masyarakat. Perpustakaan tidak lagi berperan dengan cara konvensional, namun harus sejalan dengan teknologi yang berkembang saat ini, juga masyarakat pemustaka yang dihadapi. Sebagai bagian dari layanan publik, kehadiran perpustakaan umum diharapkan menjadi tumpuan masyarakat menjadi masyarakat pembelajar. Oleh karenanya, revitalisasi peran perpustakaan umum harus diusahakan. Perpustakaan umum bukan sekadar tempat mencari informasi dan referensi, tapi menjadi sentra kegiatan belajar dan hiburan masyarakat. Menjadi tujuan masyarakat saat mengisi liburan dan waktu senggangnya.

\section{DAFTAR PUSTAKA}

Asmiyanto, Taufik. 2005. "Eksistensi Perpustakaan di Era Reformasi: Pendapat Kritis”. Makalah, Rakerpus dan Seminar Ilmiah IPI XIII Pekanbaru, Riau, 31 Mei - 3 Juni 2005, Pekanbaru: IPI, 2005, $11 \mathrm{pg}$.

Dian Sinaga. 2004. "Perpustakaan Umum Di Indonesia Sebagai Agen Dari Perubahan Social”. Jurnal Sosiohumaniora, 6 (1), Maret 2004.

Echols, John M., \& Shadily, Hasan. 1992. Kamus Inggris - Indonesia. Jakarta: Gramedia Pustaka Utama.

http://bisnis.tempo.co. 2016. perpustakaan-100-m-terbaik-dan-terbesar-di-indonesia (accessed January 5, 2016).

Junaenah, Siti. 2014. "Revitalisasi Perpustakaan Umum menjadi Dinamis, Praktis, dan Humanis". Dalam Tri Hardiningtyas, dkk. (Editor), Bunga Rampai Membangun Perpustakaan Ideal, 131-139. Yogyakarta: Smart WR. 
Kartika D., Indah. 2010. "Perpustakaan Umum Surakarta sebagai Perwujudan Ruang Komunikasi dengan Pengoptimalan Pengolahan Lansekap”. Skripsi, Fakultas Teknik UNS, Surakarta.

Kementrian Menpan RB. 2014. Top inovasi Pelayanan Publik Indonesia Tahun 2014. Jakarta: Kementrian Menpan RB.

Nurtakyidah. 2013. "Inovasi-inovasi Perpustakaan Abad 21". Jurnal Iqra, 7 (1), hlm: 30-41. Mei, 2013.

Ridarineni, Neni. www.republika.co.id. Desember 05, 2015. www.republika.co.id (accessed Mei $24,2016)$.

Undang-Undang Republik Indonesia Nomor 43 Tahun 2007 tentang Perpustakaan.

Zulaikha, Sri Rohyanti. 2008. "Kontribusi SR Ranganathan dalam Perkembangan ilmu Perpustakaan Dewasa Ini”. Fihris, 3 (1) Januari - Juni, 2008: 8 pg. 